To Cite This Article: Değirmenci, Y. (2021). Examination of teacher candidates' perception of tourists. International Journal of Geography and Geography Education (IGGE), 43, 98-107.

\title{
EXAMINATION OF TEACHER CANDIDATES' PERCEPTION OF TOURISTS
}

\author{
Yavuz DEĞiRMENCi ${ }^{1}$
}

\begin{abstract}
In today's world, tourism is one of the areas that both countries and individuals are interested in. While tourism offers opportunities to countries in various aspects primarily in economic terms, it has always been an area of interest for individuals as well. The most important actors in this area are undoubtedly individuals, in other terms, tourists. On the other hand, individuals' perception of tourists, who are in interaction with nature, the environment and local elements, is considered to be of importance and it is thought that this perception may affect tourism activities in various terms. Therefore, the present study aims to examine the tourist perceptions of teacher candidates who took tourism classes during their undergraduate education. The study was carried out with 142 teacher candidates studying in the Department of Social Studies Teaching in the Faculty of Education at a state university in Turkey in the spring semester of the 2019-2020 academic year. The qualitative phenomenology design was used in the study. The views and thoughts of the study group regarding the perception of tourists were collected through an interview form consisting of a single sentence. The content analysis technique was used in the analysis of data. According to the findings obtained from the study, the participants produced a total of 75 valid metaphors related to the concept of tourist. These metaphors were categorized based on their common properties $(n=5)$. As a result of the study, it was determined that the highest frequency of metaphors related to the concept of tourist was produced under the category "tourist as an economic element" $(n=43)$. Additionally, it was observed that the participants mostly associated tourists with metaphors such as money, bird, foreign currency, curious child and guest.
\end{abstract}

Keywords: Tourism, Tourist, Tourist Perception, Teacher Candidates, Metaphor

\footnotetext{
${ }^{1}$ Assoc. Prof., Bayburt University, Faculty of Education, Deparment of Social Studies Education, Bayburt, TURKEY., https://orcid.org/0000-0003-34171775., ydegirmenci@bayburt.edu.tr
} 


\section{INTRODUCTION}

Tourism, which is an important area in today's world, is briefly described as "trips made for pleasure" and defined as a revenue-generating service sector (Doganay, 2017) in which individuals leave their place of residence for a certain period of time and take part in various activities (İzbirak, 1986; Ozguc, 1998; Sanir, 2000; Doganay and Zaman, 2013) with the purpose of resting, having fun, traveling, exploring and discovering new places. The word tourism is derived from the Latin word "tornus" and it was passed on to Turkish from the French word "tourisme" (Akdeniz and Ardahan, 2019). The word "Tourist", which describes the most important actors and subsidiaries of the concept of tourism (Alaeddinoglu, 2007), is derived from French and used to define individuals who travel for various purposes or, according to World Tourism Organization (WTO), individuals who travel to participate in any of the tourism activities and stay in their place of travel for 24 hours at the least and 1 year at the most (Doganay and Zaman, 2013). Tourism, which is a multidimensional concept including primarily economic, social and cultural aspects, involves activities that individuals participate in with the primary purpose of resting, having fun and recreation without any intention to settle or pursue commercial and political purposes (Gurdal, 2014). Although tourism in its modern sense dates back to the 19th century, the main developments in the sector started after World War II and tourism became one of the largest and fastest-growing areas of economic activity today (Wall, 2007). However, compared to conventional tourism countries, this versatile area of activity was discovered late in our country (Doganay and Zaman, 2013). According to World Tourism Organization data, as of 2018, the tourism and travel industry constitutes $10.4 \%$ of global employment with 319 million employees around the world and one in every 10 employed individuals is a part of this sector (WTTC, 2019). On the other hand, while the number of individuals participating in international tourism activities has reached 1.326 billion as of 2017, the total tourism income has reached 1.340 billion dollars. It is estimated that the number of tourists will reach 1.8 billion people by the year 2030 (UNWTO, 2018). When the tourism statistics for Turkey are examined, it is observed that the number of tourists traveling to the country has reached 51.7 million as of 2019 , showing a $12.2 \%$ increase compared to the same period of the previous year. The tourism income has reached 34.5 billion dollars with an increase of $16.9 \%$ (Ministry of Culture and Tourism, 2019). Therefore, it is noteworthy that Turkey possesses a significant potential in terms of both the tourism sector and tourists visiting the country. When the Social Studies Curriculum and Textbooks related to the subject are examined, it is observed that various tourism-related subjects and concepts, primarily the concept of tourist, are included (ilhan, Seker and Kapici, 2015) and teachers are expected to instill these concepts into students. In order for individuals to possess knowledge in any field or subject and develop various ideas, it is important to first acquire the basic concepts related to that field in accordance with accurate and scientific facts (Akbas and Uzunoz, 2011). For this reason, metaphors were used to reveal the meanings or symbols attributed to the concept of tourist by social studies teacher candidates and their opinions and perceptions related to the concept. Explaining a concept with metaphors is to reveal the imaginary phenomenon evoked in our minds by the said concept (Ayyildiz, 2016). Metaphors, which are part of our feelings and thoughts (Sanchez, Barreiro and Maojo, 2000), is one of the most effective tools used to reveal the beliefs, personal experiences and cognitive structures of individuals related to a subject or concept (McCorkle and Mills, 1992; Mahlios and Maxson, 1998; Kalra and Baveja, 2012). According to Seferoglu, Korkmagil and Ozlu (2009), metaphors can be thought of as windows to our perception of real-life experiences and the world in general. Therefore, perception constitutes the main source of the knowledge possessed by individuals and cannot be considered independent from our experiences (Akturan and Esen, 2008). It is observed that metaphors, which are commonly encountered in daily life (Lakoff and Johnson, 2015), are widely used in studies that reveal the perceptions or thoughts of individuals regarding phenomena, events, experiences or concepts, particularly in the field of education (Degirmenci and Eskici, 2019). There are various studies in the literature related to the use of metaphors in the field of education (Saban, 2009; Harewood, 2009; Gecit, Y. and Gencer, 2011; Hamilton, 2016; Beldag and Gecit, 2017; Degirmenci, 2019). However, it can be said that there is an insufficient number of studies using metaphor analysis in the field of tourism (Erol and Düsmezkalender, 2019). On the other hand, when previous studies on tourist perception are examined, it is observed that there are various studies revealing the perceptions of tourists regarding the places they visit and reflecting the perspective of locals towards tourism and tourists (Tayfun and Kılıçlar, 2004; Alaeddinoglu, 2007: 2008; Yilmaz and Sahin, 2009; Kervankiran and Ozdemir, 2013; Yenipinar et al., 2016; Yazici et al., 2017; Sahin, Tezcan and Bekci, 2018; Erol and Düsmezkalender, 2019), however, there are a limited number of studies on how the concept is perceived by non-tourists (Gecit and Bulut, 2013). Therefore, topics such as how social studies teacher candidates, who took classes related to tourism during their undergraduate education and will teach various tourism-related concepts as part of their occupation, perceive the concept of tourism based on the images in their mind, how the concept is imprinted on their intellect and the meanings they attribute to it are considered to be significant and these subjects constitute the main reason for the present study. Additionally, answers were sought to the following questions.

- What are the metaphors used by the participants regarding their perception of "tourist"?

- Under what categories are the said metaphors gathered based on their common properties? 


\section{METHOD}

In the present study, which examines the perceptions of social studies teacher candidates related to the concept of "tourist", the qualitative phenomenology design was used. This design can be defined as placing emphasis on phenomena that we are aware of in daily life but do not have an in-depth and detailed understanding of. These phenomena can be encountered in various ways such as events, experiences, perceptions, concepts, orientations or situations. For this reason, the said design is suitable for investigating the phenomena that are not fully unknown to us but not fully comprehensible either (Yildirim and Simsek, 2011). In this approach, the researcher focuses on the personal experiences of participants and examines their perceptions regarding certain concepts or events and the meanings they attribute to events (Akturan and Esen, 2008). One of the main purposes in phenomenology studies is to reveal individuals' understanding of a specific phenomenon and classify them under conceptual categories based on their common properties (Marton, 1986). Therefore, in line with the purpose of the present study, the selection of this study design was deemed suitable with the aim of revealing the perceptions, views and thoughts of the participants regarding the concept of tourist and the common meanings they attribute to the concept.

\section{Study Group}

The study group consists of 142 teacher candidates studying in the department of Social Studies Teaching in the Faculty of Education at a state university in Turkey in the spring semester of the 2019-2020 academic year. Table 1 shows the data related to the study group.

\begin{tabular}{|lll|}
\hline & \multicolumn{2}{c|}{ Table 1: Study Group } \\
\hline Gender & Frequency (f) & Percentage (\%) \\
\hline Female & 90 & 63.38 \\
Male & 52 & 36.62 \\
\hline Total & 142 & 100 \\
\hline
\end{tabular}

Table 1 when examined, it is seen that $68.38 \%$ of the participants in the research are female students, the rate of male participants is $36.62 \%$.

\section{Data Collection}

In the data collection phase of the present study, the related literature (Marchant, 1992; Saban, 2009; Olthouse, 2014; Domović et al., 2016; Turan, 2017; Godor, 2019) was examined first and the participants were expected to fill out a semistructured form consisting of statements such as "tourists are like ......, because ......", which was also used in previous studies in the literature, with the aim of collecting the metaphors produced by the teacher candidates regarding their perceptions of the concept of tourist. The participants were asked to write metaphors related to the concept of tourist in the first space, followed by the reason for the metaphor in the second space following "because". The participants were given approximately 30 minutes to complete this process. The data obtained from these forms constituted the main data source of the study.

\section{Data Analysis}

The content analysis technique was used in the analysis of the data obtained from the participants. Content analysis is one of the most common data analysis techniques used in the fields of social science. With this technique, the data obtained is classified, the data showing similarities in various aspects are categorized under certain concepts and themes based on their common properties and these are interpreted by being arranged in a way that would enable easier comprehension for readers (Bilgin, 2014; Yildirim and Simsek, 2011). In this process, the metaphors obtained from the teacher candidates were evaluated by referring to the various steps used by Saban (2009). First, in the naming process, the metaphors produced by the participants were sorted in alphabetical order and listed. Afterwards, in the process of classification or elimination, each metaphor was examined separately and the relationship between the subject and source of the metaphor was examined to ensure that this relationship was significant. In previous studies where metaphor was used as a research tool, the concept of "like" was mainly used to evoke the link between the subject and source of metaphors more clearly. In the study, the participants were asked to present a reason or logical basis for the metaphors they produced with the concept of "because" (Saban, 2009). As a result of this examination, it was determined that not all participants were able to produce valid metaphors. The forms filled by 156 participants were examined and certain forms (14) with no metaphor sources, reasons (for example; "tourists are like birds, because ......") or logical basis (tourists are like vacations, because they are constantly on vacation), forms with only definitions and forms with blank spaces were excluded from the evaluation. After this elimination, the remaining 142 forms were evaluated. As a result of 
the evaluation, it was determined that the participants produced a total of 75 valid metaphors. In the process of category development, the 75 valid metaphors produced by the participants were gathered under 5 different categories based on their common properties. In the final step stated by Saban (2009), the validity and reliability of the study was considered. In this section, as included in the study, the data collection and data analysis processes were explained in detail. Therefore, it is considered to be important to report the data obtained and clearly state how the study results were reached by the researcher in terms of the validity of the study (Yildirim and Simsek, 2011). Additionally, principles of confidentiality were also considered in the study and the personal information of the participants was not included. Instead, the participants were classified and coded in the form of "student 1", "student 2" and "student 3" (S1; S2; S3), respectively. For the reliability of the study, expert opinion (Creswell, 2016; Yildirim and Simsek, 2011) was referred to with the aim of determining whether the metaphors presented under the obtained categories represented their respective categories. All metaphors $(n=75)$ and metaphor categories $(n=5)$ obtained were listed and presented to 2 experts in different fields. Afterwards, the reliability (Reliability Percentage=Agreement/Total Agreement + Disagreement) of the study was calculated by considering the expert feedback (Miles and Huberman, 1994). Based on the expert opinion, it was observed that two metaphors (baloon and secret box) were associated with a different category compared to the researcher's associations. For this reason, reliability was calculated as $75 / 75+2=0.97$. This result is sufficient to establish the reliability of the study (Saban, 2009). Afterwards, the data were transferred to the computer environment and their percentage (\%) and frequency $(\mathrm{f})$ values were calculated and interpreted.

\section{FINDINGS}

In this section of the study, the metaphors produced by the participants regarding the concept of "tourist" and metaphor categories were presented in tables and interpreted. Table 2 shows the metaphors produced by the participants regarding the concept of "tourist".

\begin{tabular}{|c|c|c|c|c|c|}
\hline Metaphor Produced & (f) & (\%) & Metaphor Produced & (f) & (\%) \\
\hline Money & 14 & 9.85 & ATM & 1 & 0.70 \\
\hline Bird & 8 & 5.63 & Flag & 1 & 0.70 \\
\hline Foreign Currency & 5 & 3.52 & Fertile Soil & 1 & 0.70 \\
\hline Curious Child & 5 & 3.52 & Brain & 1 & 0.70 \\
\hline Guest & 5 & 3.52 & Learned Person & 1 & 0.70 \\
\hline Water & 5 & 3.52 & Blank Notebook & 1 & 0.70 \\
\hline Sun & 4 & 2.81 & Wheat Field & 1 & 0.70 \\
\hline Book & 4 & 2.81 & Trash & 1 & 0.70 \\
\hline Pilgrim/Traveler & 4 & 2.81 & Valuable Vase & 1 & 0.70 \\
\hline Flower & 3 & 2.11 & Sea & 1 & 0.70 \\
\hline World & 3 & 2.11 & Inflation & 1 & 0.70 \\
\hline Migratory Bird & 3 & 2.11 & Planet & 1 & 0.70 \\
\hline Curious Person & 3 & 2.11 & Secret Box & 1 & 0.70 \\
\hline Fruit & 3 & 2.11 & Rainbow & 1 & 0.70 \\
\hline Newborn Baby & 3 & 2.11 & Balloon & 1 & 0.70 \\
\hline Gold & 2 & 1.40 & Weather Forecast & 1 & 0.70 \\
\hline Bank & 2 & 1.40 & Animal & 1 & 0.70 \\
\hline Dollar & 2 & 1.40 & Recreational Vehicle & 1 & 0.70 \\
\hline Mine & 2 & 1.40 & Ant & 1 & 0.70 \\
\hline Petrol & 2 & 1.40 & Cat & 1 & 0.70 \\
\hline Wind & 2 & 1.40 & Caravan & 1 & 0.70 \\
\hline Capital & 2 & 1.40 & Grain of Sand & 1 & 0.70 \\
\hline Field & 2 & 1.40 & Cultural Ambassador & 1 & 0.70 \\
\hline Train & 2 & 1.40 & Stork & 1 & 0.70 \\
\hline Foreigner & 2 & 1.40 & Media & 1 & 0.70 \\
\hline Tree & 1 & 0.70 & Fruit Tree & 1 & 0.70 \\
\hline Stream & 1 & 0.70 & Bus & 1 & 0.70 \\
\hline Shopping Mall & 1 & 0.70 & Alien & 1 & 0.70 \\
\hline Golden Goose & 1 & 0.70 & University Student & 1 & 0.70 \\
\hline Car & 1 & 0.70 & Step-Sibling & 1 & 0.70 \\
\hline Bee & 1 & 0.70 & Wagon & 1 & 0.70 \\
\hline Smokeless Industry & 1 & 0.70 & Fertile Plain & 1 & 0.70 \\
\hline Garden & 1 & 0.70 & Rain & 1 & 0.70 \\
\hline Teacher & 1 & 0.70 & Rain Cloud & 1 & 0.70 \\
\hline Guide & 1 & 0.70 & False Spring & 1 & 0.70 \\
\hline Watch & 1 & 0.70 & Half-Full Glass & 1 & 0.70 \\
\hline Peddler & 1 & 0.70 & Old Person & 1 & 0.70 \\
\hline Plane & 1 & 0.70 & - & & \\
\hline
\end{tabular}


Table 2 shows that a total of 75 valid metaphors were produced by the participants regarding the concept of tourist. When these metaphors were examined, it was determined that 50 metaphors were used by the participants once while 25 metaphors were used more than once. 9.85\% of the participants $(f=14)$ associated the concept of tourist with "money" while $5.63 \%$ of the participants $(f=8)$ associated the concept with "bird". Other than these, the metaphors that were most commonly associated with the concept of tourist were "foreign currency" $3.52 \%(f=5)$, "curious child" $3.52 \%(f=5)$, "guest" $3.52 \%(f=5)$, "water" 3.52\% ( $f=5)$, "sun" 2.81\% ( $f=4)$, "book" 2.81\% $(f=4)$, and "pilgrim/traveler" 2.81\% ( $f=4)$. Table 3 shows the categories of the metaphors developed by the teacher candidates.

\begin{tabular}{|c|c|c|c|c|}
\hline Categories & Metaphors & Number & Frequency & Percentage \\
\hline $\begin{array}{l}\text { Tourist as a Tangible } \\
\text { and Natural Element }\end{array}$ & $\begin{array}{l}\text { Water (5), sun (4), flower (3), world (3), fruit (3), } \\
\text { wind (2), tree (1), stream (1),garden (1), blank } \\
\text { notebook (1), trash (1), sea (1), secret box (1), } \\
\text { rainbow (1), balloon (1), weather forecast (1), } \\
\text { grain of sand (1), fruit tree (1), watch (1), rain } \\
\text { (1), rain cloud (1), false spring (1), half-full glass } \\
\text { (1) }\end{array}$ & 23 & 37 & 26.05 \\
\hline $\begin{array}{l}\text { Tourist as an Economic } \\
\text { Element }\end{array}$ & $\begin{array}{l}\text { Money (14), foreign currency (5), gold (2), bank } \\
\text { (2), dollar (2), mine (2), petrol (2), capital (2), } \\
\text { field (2), golden goose (1), smokeless industry } \\
\text { (1), ATM (1), fertile soil (1), wheat field (1), } \\
\text { valuable vase (1), inflation (1), peddler (1), fertile } \\
\text { plain (1), shopping mall (1) }\end{array}$ & 19 & 43 & 30.28 \\
\hline $\begin{array}{l}\text { Tourist as a Social and } \\
\text { Cultural Element }\end{array}$ & $\begin{array}{l}\text { Curious child (5), guest (5), book (4), curious } \\
\text { person (3), newborn baby (3), foreigner (2), flag } \\
\text { (1), brain (1), learned person (1), cultural } \\
\text { ambassador (1), teacher (1), guide (1), alien (1), } \\
\text { university student (1), step-sibling (1), old } \\
\text { person (1), media (1) }\end{array}$ & 17 & 33 & 23.23 \\
\hline $\begin{array}{l}\text { Tourist in the Classical } \\
\text { Sense }\end{array}$ & $\begin{array}{l}\text { Pilgrim/traveler (4), train (2), car (1), planet (1), } \\
\text { recreational vehicle (1), caravan (1), bus (1), } \\
\text { plane (1), wagon (1), }\end{array}$ & 9 & 13 & 9.15 \\
\hline $\begin{array}{l}\text { Tourist as an Animal } \\
\text { Element }\end{array}$ & $\begin{array}{l}\text { Bird (8), migratory bird (3), bee (1), animal (1), } \\
\text { ant (1), cat (1), stork (1) }\end{array}$ & 7 & 16 & 11.26 \\
\hline Total & & 75 & 142 & 100 \\
\hline
\end{tabular}

Table 3 shows that the metaphors produced by the participants were gathered under 5 different categories based on their various common properties. These categories can be listed as (1) "Tourist as a Tangible and Natural Element", (2) "Tourist as an Economic Element", (3) "Tourist as a Social and Cultural Element", (4) "Tourist in the Classical Sense" and (5) "Tourist as an Animal Element", respectively. It is also observed that 37 teacher candidates produced a total of 23 different metaphors under the category "Tourist as a Tangible and Natural Element". 43 teacher candidates produced a total of 19 different metaphors under the category "Tourist as an Economic Element". 33 teacher candidates produced a total of 17 different metaphors under the category "Tourist as a Social and Cultural Element". 13 teacher candidates produced a total of 9 different metaphors under the category "Tourist in the Classical Sense" while 16 teacher candidates produced a total of 7 different metaphors under the category "Tourist as an Animal Element". Figure 1 shows the word cloud regarding the metaphors that were used more than once.

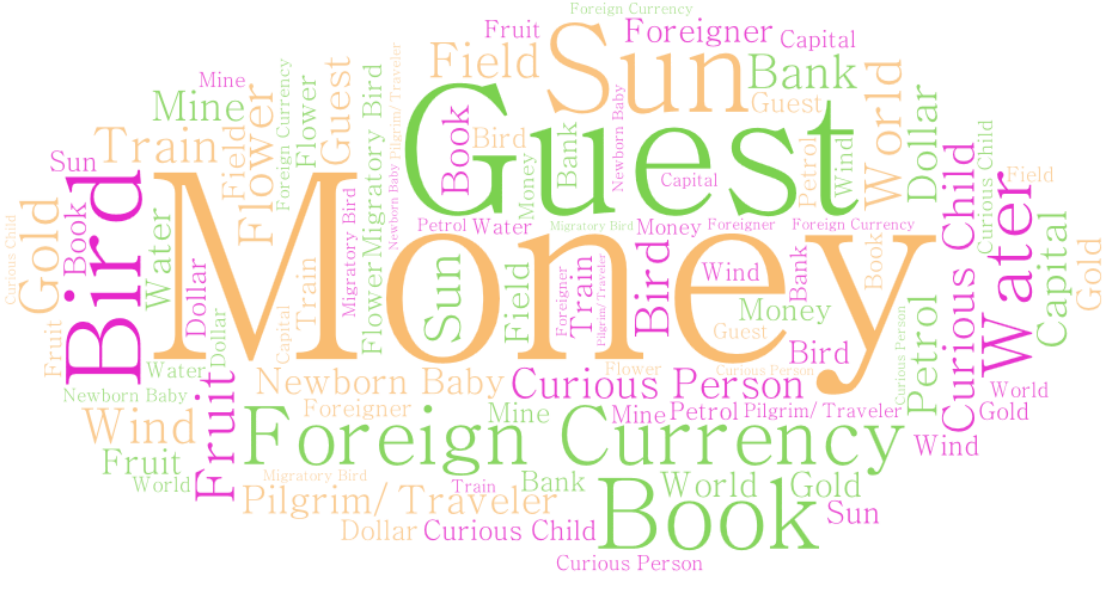

Figure 1: The Word Cloud Regarding the Concept of Tourist 
Some sample expressions of the teacher candidates regarding the concept of tourist were presented below.

\section{Category 1. Tourist as a Tangible and Natural Element:}

When Table 3 is examined, it is observed that repeated metaphors such as water (5), sun (4), flower (3), fruit (3), wind (2) and metaphors that were used once such as "tree, stream, garden, blank notebook, trash, sea, secret box, rainbow, balloon, weather forecast, grain of sand, fruit tree, watch, rain, rain cloud, false spring and half-full glass" are included in this category. Additionally, this category stands out in terms of the number of metaphors $(n=23)$ as it is the one in which the most metaphors were developed. The sample metaphor expressions created by the teacher candidates regarding this category are presented below.

"Tourists are like water, because they can be found everywhere." (S4)

"Tourists are like the sun, because just as there can be no world without the sun, there can be no country without tourists." (S50)

"Tourists are like flowers, because they can be seen in different places in all seasons." (S91)

"Tourists are like fruits, because they are seasonal as well. There are more of them in summer, less of them in winter." (S30).

"Tourists are like the wind, because they are not stationary, they wander continuously." (S70).

\section{Category 2. Tourist as an Economic Element:}

Under this category, 43 participants produced 19 different metaphors. This category is also the one in which the most participants $(n=43)$ stated their opinions. It is observed that the metaphors money (14), foreign currency (5), gold (2), bank (2), dollar (2), mine (2), petrol (2), capital (2) and field (2) were used more than once. The other metaphors were used once by the participants. The sample metaphor expressions created by the teacher candidates regarding this category are presented below.

"Tourists are like money, because they revitalize the economy." (S72)

"Tourists are like money, because they increase the economic wealth and growth of the countries they visit." (S43)

"Tourists are like foreign currency, because they provide inflow of foreign currency to the countries they visit." (S81).

"Tourist is like gold, because they are of great importance in terms of our country's economy." (S51).

"Tourists are like dollar, because they contribute to national economy." (S116).

\section{Category 3. Tourist as a Social and Cultural Element:}

Under this category, 33 participants produced 17 different metaphors. It is observed that the metaphors curious child (5), guest (5), book (4), curious person (3), newborn baby (3) and foreigner (2) were used more than once. The other metaphors were used once by the participants. The sample metaphor expressions created by the teacher candidates regarding this category are presented below.

"Tourists are like curious children, because children always want to stroll and discover new thinks. Tourists are like that too." (S59)

"Tourists are like guests, because the better they are hosted, the more satisfied they are and more likely to revisit." (S136)

"Tourists are like books, because as we read them, we notice and learn about their culture and country of origin." (S63).

"Tourists are like a curious person, because they also have a sense of curiosity and exploration." (S22).

"Tourists are like newborn babies, because they explore places that are unknown to them and learn new things." (S39)

\section{Category 4. Tourist in the Classical Sense:}

Under this category, 13 participants produced 9 different metaphors. These can be listed as pilgrim/traveler (4), train (2), car (1), planet (1), recreational vehicle (1), caravan (1), bus (1), plane (1) and wagon (1). The sample metaphor expressions created by the teacher candidates regarding this category are presented below.

"Tourists are like pilgrims, because they travel, learn and increase their knowledge at the same time." (S48)

"Tourists are like trains, because they always have passengers." (S128) 
"Tourists are like planets, because they always roam." (S15).

\section{Category 5. Tourist as an Animal Element:}

This category includes the least number of metaphors related to the concept of tourist with 7 different metaphors from 16 participants. These can be listed as bird (8), migratory bird (3), bee (1), animal (1), ant (1), cat (1) and stork (1). The sample metaphor expressions created by the teacher candidates regarding this category are presented below.

"Tourists are like birds, because they are free to fly and land wherever they want." (S122)

"Tourists are like migratory birds, because they migrate only at certain times." (S9)

"Tourists are like bees, because they collect different things from different cultural groups." (S121)

"Tourists are like ants, because they lead others to the places they like." (S11)

\section{DISCUSSION, CONCLUSION AND SUGGESTIONS}

The tourism sector, which is one of the most popular areas of activity in today's world, has been increasing its growth rate day by day compared to other areas. It can be said that this development process began symbolically with the invention of the wheel in the early ages and gained momentum following the Industrial Revolution and World War II (Doganay and Zaman, 2013). On the other hand, tourists are one of the most dynamic components of the tourism sector. In the present study, which examined the tourist perceptions of teacher candidates through the use of metaphors, it was observed that the participants produced a total of 75 valid metaphors related to the concept of tourist and these metaphors were gathered under 5 categories based on their common properties. The participants mainly associated the concept of tourist with metaphors such as money, bird, foreign currency, curious child, guest, water, sun, book, pilgrim/traveler, flower, world and migratory bird. When the related literature is examined, it is observed that there are certain similarities between the findings of the present study and the study conducted by Gecit and Bulut (2013). In the said study, it is observed that the participants mainly associated the concept of tourist with metaphors such as money, bee, pilgrim, traveler, bank, walking dollar and bird. In the study conducted by Erol and Dsşmezkalender, (2019) on the perceptions of the local population of "Ürgüp" regarding the concepts of tourism and tourist, it was found that the local population mainly associated the concept of tourist with metaphors such as guest, bread, water, cultural wealth, income, human and philanthropist. In other studies, it is observed that the concept of tourist was associated with metaphors such as children (Chi Vu, 2014; Daher, 2006), pilgrim or curious person (Karnatz, 2016), guest (Alaeddinoglu, 2008), explorer (Frost and Laing, 2015) or, as seen in another study (Thomas, 2017), a person who visits stereotypical places.

As a result of the study, the teacher candidates produced various metaphors related to the concept of tourists and these metaphors were gathered under 5 categories based on their common properties. When the results of the previous studies in the literature conducted with metaphors are examined (McGrath, 2006; Saban, 2009; Olthouse, 2014; Kaphesi, 2014; Gökce, 2016; Domović, Vlasta and Bouillet, 2017; Turan, 2017; Ma and Gao, 2017; Degirmenci, 2019), it is observed that the participants produced different numbers of metaphors related to the concepts subject to study and that these metaphors were categorized by the researchers based on their various properties. Geçit and Bulut (2013) evaluated the metaphors developed by the participants related to tourist perception under 4 different categories while Erol and Düsmezkalender (2019) evaluated them under 5 different categories.

Based on the metaphors developed as a result of the study (for example; bird, book, guest, curious child, sun, fruit, pilgrim, flower and world), it can be said that the tourist perceptions of the participants were generally positive, although there were some negative metaphors (for example; trash and false spring). In contrast to this result, in the study conducted by Gecit and Bulut (2013) with teacher candidates, it was stated that the tourist perceptions of the participants were positive, meaning that there was no negative perception towards tourists. The researchers attributed the reason for this situation to the tourism activities in the region where the study was conducted and the fact that the majority of the participants were from the said region. In the study conducted by Erol and Düsmezkalender (2019), it was observed that while the general perception of the local population was positive, a small number of negative metaphors (insatiable person, cultural disagreement and problematic money) were also used. In another study (Alaeddinoglu, 2008), it was emphasized that $91.3 \%$ of the participants had positive perceptions towards tourists and that the educational background of individuals was directly proportionate to their tourist perceptions. Similarly, it was found by Filiz and Yılmaz (2017) that the local population had a positive perception of tourists due to economic reasons while Sandal and Karademir (2016) determined that approximately $84 \%$ of the participants had positive perceptions due to economic reasons.

In the present study, it was determined that $30.28 \%$ of the participants associated the concept of tourist with economic elements and the most metaphors were developed in the category "Tourist as a Tangible and Natural Element" ( $n=23$ ) 
while the least metaphors were developed in the category "Tourist as an Animal Element" ( $n=7)$. When the study conducted by Gecit and Bulut (2013) is examined in relation to the aforementioned results, it was observed that the tourist perceptions of the participants were mainly related to economic reasons $(n=27)$ and that the most participants $(f=41)$ produced metaphors in this category. On the other hand, it was observed that the least number of participants $(\mathrm{f}=4)$ produced metaphors in the category "Tourist in Advertisement Terms" $(\mathrm{n}=2)$. Similarly, Erol \& Düsmezkalender (2019) found that the tourist perceptions of the participants were mainly related to economic reasons. In the said study, it was observed that $26 \%$ of the participants produced metaphors in the category "Tourist as an Economic Perception" while $8 \%$ of the participants produced metaphors in the category "Tourist as a Natural Perception". In another study (Alaeddinoglu, 2008), in response to the question "what does the concept of tourist mean to you?", $51.2 \%$ of the participants perceived tourists in relation to economic growth while $40.1 \%$ perceived them as individuals who produced inflow of foreign currency.

In conclusion, when the findings of the aforementioned studies are taken into consideration, it can be argued that the tourist perceptions of the participants are based on economic reasons and the concept of tourism was mainly associated with this dimension. In light of these findings, the following suggestions are presented.

- Future studies can be conducted on the reasons behind the positive or negative perceptions of individuals towards tourists.

- Different quantitative and qualitative studies can be conducted to reveal the tourist perceptions of individuals with the aim of contributing to increasing the number of tourists and further developing the tourism sector, which is an important economic factor for countries and Turkey in particular.

- While the development and diversification of tourism activities in a given place may be associated with many reasons, it is also based on the perspective and perception of non-tourists and the local population towards tourists. For this reason, activities or applications that reveal the perceptions of non-tourists and enable them to develop positive perceptions can be carried out.

- Finally, the findings that revealed the tourist perceptions of the participants in the present study may be referred to in future studies on tourism activities or tourists.

\section{ACKNOWLEDGEMENTS}

This research did not receive any specific grant from funding agencies in the public, commercial, or not-for-profit sectors.

\section{References}

Akbas, Y. \& Uzunoz, A. (2011). Teach of geography based on conceptual chance approach; an example of implementation. e-Journal of New World Sciences Academy, 6(2), 1659-1678.

Akdeniz, Y. \& Ardahan, F. (2019). Tennis tourism and tennis economy: the case of Antalya. 2nd International Congress on Recreation and Sports Management, 11-14 April. Bodrum.

Akturan, U. \& Esen, A. (2008). Phenomenology. In Bas, T. \& Akturan, U. (Eds.), Advanced Qualitative research methods (pp. 83-94). Ankara: Seckin publications.

Alaeddinoglu, F. (2007). Community's view to tourism and tourists in the city of Sivas. Journal of Human Sciences, 5(2), 1-23.

Alaeddinoglu, F. (2007). Tourist profile and tourism perception stile of the people of Van. Turkish Journal of Geographical Sciences, 5(1), 1-16.

Beldag, A. \& Gecit, Y. (2017). Social studies teachers' perceptions regarding the concept "geography": a phenomenological study. Eastern Geographical Review, 22(37), 99-112.

Bilgin, N. (2014). Content Analysis in Social Sciences. Ankara: Siyasal Bookstore.

Chi V. (2014). The generation Vietnamese-American writer as post-colonial translator. The AALITRA Review: A Journal of Literary Translation. 9, 5-18.

Creswell, J. W. (2016). Nitel Araştırma Yöntemleri. (Çev. M. Bütün \& S.B. Demir). (3. Baskı). Ankara: Siyasal Kitapevi.

Daher, R.F. (2006). Tourism in the Middle East. Toronto: Channel View Publications.

Degirmenci, Y. \& Eskici, B. (2019). Examination of prospective teachers' perceptions of active citizenship. OPUS International Journal of Society Researches, 11(18), 233-256.

Degirmenci, Y. (2019). An examination of metaphors regarding the concept of "natural disaster" developed by prospective classroom teachers. International Journal of Geography and Geography Education, 39, 83-94.

Doganay, H. \& Zaman, S. (2013). Turkey Tourism Geography. Ankara: Pegem Academy Publications.

Doğanay, H. (2017). Geography Science Fields Glossary. N.T. Altaş (Ed.), Ankara: Pegem academy publications. 
Domović, V., VidovićVlasta, V. \& Bouillet, D. (2016). Student teachers' beliefs about the teacher's role in inclusive education. European Journal of Special Needs Education, 32(2), 175-190.

Erol, G. \& Düsmezkalender, E. (2019). Analysis of the concepts of tourism and tourist by metaphors. 4th International Tourism Congress. 16-19 October, Eskişehir.

Filiz, A. \& Yilmaz, Ö.D. (2017). Residents' perception and attitudes towards tourism within the scope of tourism development approaches: comparative analysis of Mazı Village-Türkbükü. Hitit University Journal of Social Sciences Institute, 10(2), 17991824.

Frost, W. \& Laing, J. (2015). On the trail of errol flynn: explorations in autoethnography. Tourism Analysis, 20, 283-296.

Gecit, Y. \& Bulut, N. (2013). Perceptions of prospective teachers towards the concept of "tourist" and their views on developing tourism in the Eastern Black Sea Region. 2nd Rize development symposium. 3-4 May, Rize.

Gecit, Y. \& Gencer, G. (2011). Determining the geographical perception of the 1st. grade students in the department of primary education through metaphor (example of Rize University). Marmara Coğrafya Dergisi, 23, 1-19.

Godor, B. P. (2019). Gifted metaphors: exploring the metaphors of teachers in gifted education and their impact on teaching the gifted. Roeper Review, 41, 51-60.

Gökce, N. (2016). Social studies teacher candidates' metaphors about the concept of geography. The Journal of International Education Science, 3(9), 121-134.

Gurdal, M. (2014). Turkey Tourism Geography. Professional Tourist Guide and Travel Guide. Ankara: Nobel Academy Publications.

Hamilton, E. R. (2016). Picture this: multimodal representations of prospective teachers' metaphors about teachers and teaching. Teaching and Teacher Education, 55, 33-44.

Harewood, S. (2009). Metaphor and the work of cultural studies. Policy Futures in Education, 7(2), 161-171.

Ilhan, G.O., Seker, M. \& Kapici, H.O. (2019). Examination of tourism concept in fifth grade social studies textbooks. International Journal of Field Education, 1(1), 42-62.

Izbırak, R. (1986). Geography Terms Dictionary. Istanbul: Ministry of National Education Teacher Books Series.

Kalra, M. B. \& Baveja, B. (2012). Teacher thinking about knowledge, learning and learners: a metaphor analysis. Procedia-Social and Behavioral Sciences, 55, 317-326.

Kaphesi, E. (2014). Third-year university mathematics education students' metaphorical understanding of mathematics teaching and learning. African Journal of Research in Mathematics, Science and Technology Education, 18(3), 276-286.

Karnatz, A. (2016). Tourist or traveler a study on social categorization among non-residents in Gothenburg. Cultural sciences, bachelor's programme, Bachelor thesis in cultural sciences. Department of Cultural Sciences, Gothenburg University.

Kervankıran, i. \& Özdemir, A. (2013). A study on the tourist perception in the province of Afyonkarahisar undergoing tourism development. Marmara Geography Journal, 27, 117-142.

Lakoff, G. \& Johnson, M. (2015). Metaphors Life, Meaning and Language. (Trans: Demir, G.Y). Istanbul: İthaki.

Ma, X. \& Gao, X. (2017) Metaphors used by pre-service teachers of Chinese as an international language. Journal of Education for Teaching, 43(1), 71-83.

Mahlios, M. \& Maxson, M. (1998). Metaphors as structures for elementary and secondary preservice teachers' thinking. International Journal of Educational Research, 29, 227-240.

Marchant, G. J. 1(992) A teacher is like a: Using simile lists to explore personal metaphors. Language and Education, 6, 33-45.

Marton, F. (1986). Phenomenography: A research approach to investigating different understanding of reality. Journal of Tought, 21(3), 28-49.

McCorkle, S. \& Mills, J.L. (1992). Rowboat in a hurricane: Metaphors of interpersonal conflict management. Communication Reports, $5(2), 57-66$.

McGrath, I. (2006). Teachers' and learners' images for coursebooks. ELT Journal, 60(2), 171-180.

Miles, M. B. \& Huberman, M. A. (1994). An Expanded Sourcebook Qualitative Data Analysis. London: Sage.

Ministry of Culture and Tourism, (2019). Tourism statistics, general evaluation. Retrieved August 2019, from: https://yigm.ktb.gov.tr/Eklenti/69320,turizmistatistikleri2019-4pdf.pdf?0.

Olthouse, J. (2014). How do preservice teachers conceptualize giftedness? a metaphor analysis. Roeper Review, 36(2), 122-132.

Ozgüc, N. (1998). Tourism Geography. Features-Regions. Istanbul: Cantay Bookstore.

Saban, A. (2009). Prospective teachers' mental Images about the concept of student. The Journal of Turkish Educational Sciences, 7(2), 281-326.

Sahin, S., Tezcan, A.B. \& Bekci, M. (2018). Native tourists metaphors about Turkey, Istanbul, tourism and tourist guide. Tourism Academic Journal, 5(1), 261-274.

Sanchez, A., Barreiro, J.M. \& Maojo, V. (2000). Design of virtual reality systemsf or education: A cognitive approach. Education and Information Technologies, 5(4), 345-362.

Sandal, E.K. \& Karademir, N. (2016). Public view about tourism in Kahramanmaraş. Turkish Geography Review, 66, 63-70. 
Sanir, F. (2000). Geography Terms Dictionary. Ankara: Gazi Office Bookstore.

Seferoglu, G., Korkmazgil, S. \& Olcu, Z. (2009). Gaining insights into teachers' ways of thinking via metaphors. Educational Studies, 35(3), 323-335.

Tayfun, A. \& Kiliclar A. (2004). Social implications of tourism and host community's perception of tourism. Gazi University, Journal of the Faculty of Commerce and Tourism, 1,1-17.

Thomas, K.i. (2017). The awe in awesome: A multidisciplinary approach sheds light on education abroad. (Unpublished doctoral dissertation. The Pennsylvania State University).

Turan, i. (2017). Primary school teacher candidates' metaphors for nuclear power stations. International Journal of Economic Studies, 4, 569-579.

UNWTO. (2018). Tourism highlights, 2018 edition. United Nations World Tourism Organisation. Retrieved September 12, 2020, from https://www.e-unwto.org/doi/pdf/10.18111/9789284419876.

Wall, G. (2007), The tourism industry and its adaptability and vulnerability to Climate Change. İ B. Amelung, K. Blazejczyk, A. Matzarakis (Eds.), Climate change and tourism: Assessment and coping strategies (pp.5-19). University of Freiburg, Freiburg.

WTTC. (2019). Travel and tourism economic impact 2019. World travel \& tourism council. Retrieved September 12, 2020, from https://www.slovenia.info/uploads/dokumenti/raziskave/raziskave/world2019.pdf.

Yazici, H., Koca, M.K., Ekiz, E. \& Akpinar, E. (2017). Views of pre-service social studies teachers' on tourism in Afyonkarahisar. Anadolu Journal of Educational Sciences International, 7(3), 458-485.

Yenipınar, U., Bak, E., Cınar, B., Bildir, S.S. \& Capar, G. (2016). Analysis of perceptions of undergraduate students of tourism guidance department on tourist guiding profession with metaphors. 17th national tourism congress. 20-23 October, Muğla.

Yıldırım, A. \& Simsek, H. (2011). Qualitative Research Methods in the Social Sciences. Ankara: Seckin Publishing.

Yilmaz, A. \& Sahin, K. (2009). The tourism and the tourist perception in Samsun city and immediate surroundings The Journal of International Social Research, 2(7), 345-358. 